\title{
Split immunological tolerance to trophoblast
}

\author{
AMANDA DE MESTRE ${ }^{1}$, LEELA NORONHA ${ }^{2}$, BETTINA WAGNER ${ }^{3}$ and DOUGLAS F. ANTCZAK*,2 \\ ${ }^{1}$ Department of Veterinary Basic Sciences, The Royal Veterinary College, Royal College Street, London, UK, \\ ${ }^{2}$ Baker Institute for Animal Health, College of Veterinary Medicine, Cornell University, Ithaca, New York, \\ USA and ${ }^{3}$ Department of Population Medicine and Diagnostic Sciences, College of Veterinary Medicine, \\ Cornell University, Ithaca, New York, USA
}

\begin{abstract}
Split immunological tolerance refers to states in which an individual is capable of mounting certain types of immune responses to a particular antigenic challenge, but is tolerant of the same antigen in other compartments of the immune system. This concept is applicable to the immunological relationship between mother and fetus, and particularly relevant in equine pregnancy. In pregnant mares, antibody responses to paternal foreign Major Histocompatibility Complex class I antigens are robust, while anti-paternal cytotoxic $\mathrm{T}$ cell responses are diminished compared to those mounted by non-pregnant mares. Here, we compared the distribution of the major lymphocyte subsets, the percentage of lymphocytes expressing Interferon Gamma (IFNG) and Interleukin 4 (IL4) and the level of expression of the immunoregulatory transcription factor FOXP3 between pregnant and non-pregnant mares, and between peripheral blood and the endometrium during pregnancy. In a cohort of mares in which peripheral blood lymphocytes were tested during early pregnancy and in the non-pregnant state, there were only slight changes observed during pregnancy. In contrast, comparison of peripheral blood lymphocytes with lymphocytes isolated from the endometrial cups of pregnant mares revealed striking differences in lymphocyte sub-populations. The endometrial cups contained higher numbers of IFNG+ lymphocytes, and lower numbers of lymphocytes expressing IL4. The endometrial cup lymphocytes also had higher numbers of FOXP3+ cells compared to peripheral blood lymphocytes. Taken together, these results strengthen the evidence for a state of split tolerance to trophoblast, and furthermore define sharp differences in immune reactivity during equine pregnancy between peripheral blood lymphocytes and lymphocytes at the maternal-fetal interface.
\end{abstract}

KEY WORDS: trophoblast, pregnancy, tolerance, cytokine, lymphocyte

\section{Introduction}

The paradox of the successful fetus-as-allograft paradigm was first proposed by Peter Medawar in 1953, and hypotheses put forth in that classic paper have generated numerous clinical and experimental studies in the field of pregnancy immunology. Now 56 years later, many strategies and mechanisms have been identified that may explain how the fetus escapes recognition and destruction by the maternal immune system. These include repression of expression of alloantigens and tissue specific antigens in the placenta, systemic alterations in the character of maternal immune responses during pregnancy, and locally operating mechanisms of trophoblast cells that protect the fetal tissues against destruction by maternal immune effector cells and molecules. Progress in these areas has been evaluated in a number of comprehensive reviews (Billington, 2003; Caucheteux et al., 2003; Koch and Platt, 2003; Hunt, 2006; Moffett and Loke, 2006; Trowsdale and Betz, 2006; Zenclussen et al., 2007; Seavey and Mossman, 2008).

In descriptions of the fetal-maternal immunological relationship, the concept of maternal tolerance to the fetus is often used (Mellor and Munn, 2000; Robertson and Sharkey, 2001; Kannellopoulos-Langevin et al., 2003; Aluvihare et al., 2004; Blois et al., 2007). Although immunological tolerance is well

\footnotetext{
Abbreviations used in this paper: CTL, cytotoxic T cell; eCG, equine chorionic gonadotropin; FoxP3, forkhead box P3; IFNG, interferon gamma; IL, interleukin; MHC, major histocompatibility complex; Tregs, regulatory T cells; UBE2D2, ubiquitin conjugating enzyme E2D 2.
}

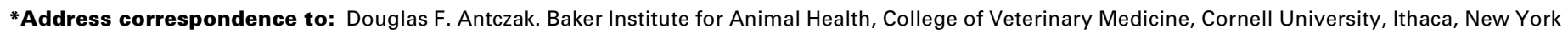
14853 USA. Fax: +1-607-256-5608. e-mail: dfa1@cornell.edu
}

Final author-corrected PDF published online: 16 October 2009.

ISSN: Online 1696-3547, Print 0214-6282

() 2009 UBC Press

Printed in Spain 
understood operationally, tolerance can be achieved by many distinct mechanisms, and not all of them have yet been elucidated. A number of experimental approaches have identified both antigen-specific and non-specific tolerogenic mechanisms operating during pregnancy. In T cell transgenic mice there is evidence for either deletion or inactivation of T cells (Tafuri et al., 1995; Jiang \& Vacchio, 1998) or B cells (Ait-Azzouzene et al., 1998, 2001) reactive with paternal Major Histocompatibility Complex (MHC) class I antigens or the $\mathrm{H}-\mathrm{Y}$ minor histocompatibility antigen. The antigen-specific effects have largely been detected using transgenic mice expressing only a single specificity of T cell receptor, whereas non-specific mechanisms have been detected in normal mice (Krishnan et al., 1996a, b; Aluvihare et al., 2004; Pejcic-Karapetrovic et al., 2007).

It is not clear if and how these two principal types of fetomaternal tolerance are related. Antigen specific mechanisms have the great advantage of leaving the remainder of the mother's
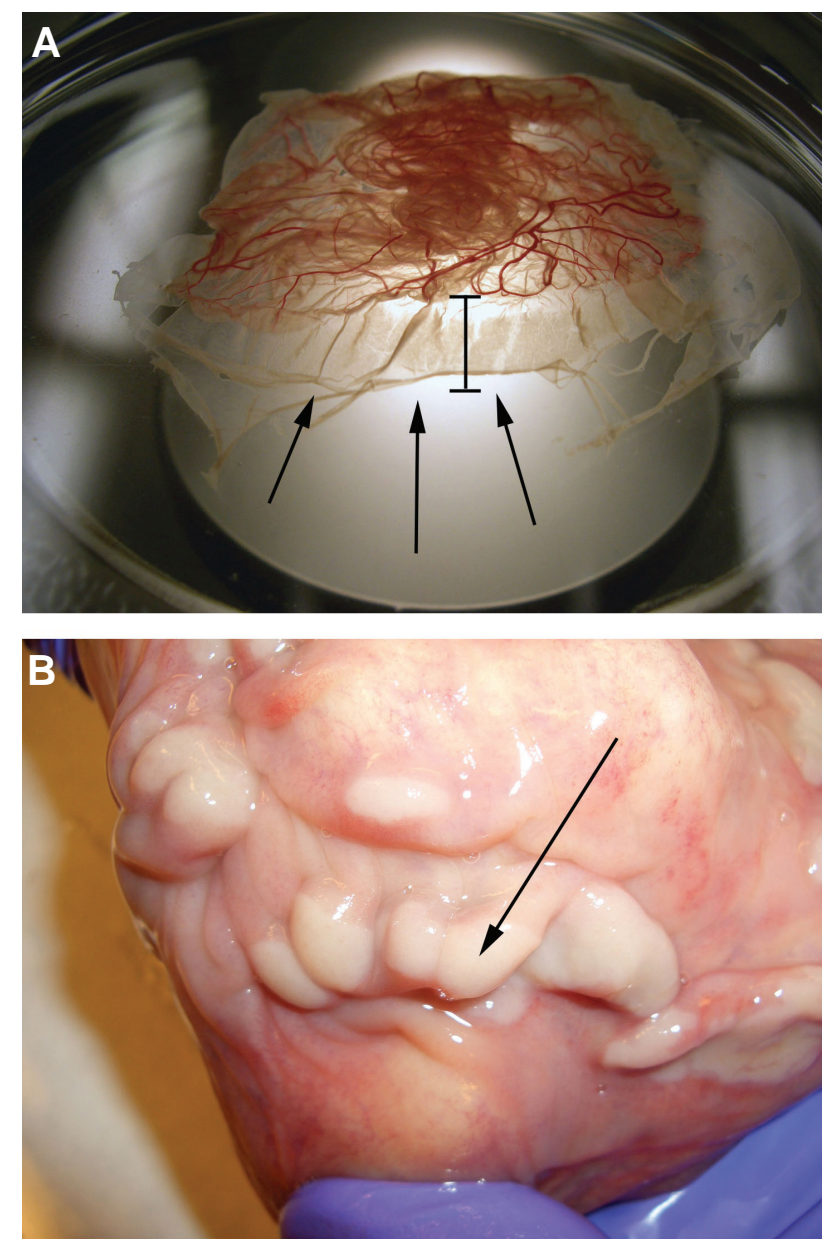

Fig. 1. Gross specimens of day 34 equine conceptus and endometrial cups from day $\mathbf{4 5}$ of gestation. (A) Day 34 conceptus showing the horizontal band of invasive trophoblast of the chorionic girdle, demarcated by the vertical bracket and arrows. At day 36-38 of gestation the chorionic girdle cells migrate into the endometrium to form the mature, eCG secreting endometrial cups. Specimen obtained by non-surgical uterine lavage. (B) Mature endometrial cups at day 45 of gestation shown in the endometrium. Arrow points to a strip of cups, which average $1 \mathrm{~cm}$ in diameter. Specimen obtained at necropsy. immune system intact, allowing her to defend herself against infection during pregnancy. However, they also require that the conceptus express the antigens to which tolerance is induced. The antigen non-specific mechanisms of tolerance do not require information about the specific histocompatibility challenge of the fetus. Their disadvantage, however, is that they might alter the mother's immune system in ways that would make her more susceptible to certain types of infection during pregnancy. The increased susceptibility of pregnant women to Toxoplasma and Listeria infection may reflect such an untoward effect (Smith, 1999; Avelino et al., 2003).

The mechanisms by which maternal tolerance to the fetus is induced are not yet fully understood, but critical components may include local signals from sperm, seminal fluid, the developing conceptus, the hormonal state of pregnancy, and in the case of antigen-specific tolerance, expression of MHC molecules by the conceptus in a context that favors tolerance over immunity (Robertson et al., 1997; Robertson \& Sharkey, 2001). The detection of expanded numbers of circulating or locally accumulated regulatory T cells (Tregs) in normal mouse (Aluvihare et al., 2004; Zenclussen et al., 2006) and human (Tilburgs et al., 2008) pregnancy provides a framework focused on a CD4+CD25+ FOXP3+ T cell (Ramsdell, 2003; Wood \& Sakaguchi, 2003; Nagler-Anderson et al., 2004).

The term 'split tolerance' has two meanings in immunology. In the context of tissue and organ transplantation, it refers to the observation that grafts of some tissues, classically liver, may be accepted by a recipient while grafts of other tissues from the same donor, for example, skin, are rejected (Qian et al., 1997; Chan et al., 2008; Chung etal., 2005; Luo etal., 2007; Mathes etal., 2003). The second and more relevant use of the term for this study has broader implications in immunological tolerance. It refers to states in which an individual is capable of making some types immunological responses to a particular antigenic challenge, but is apparently tolerant to the same antigen from the perspective of other immune system compartments (Sprent et al., 1995; Hunziker etal., 1997; Baker etal., 2001). Although the mechanisms leading to split tolerance are not well understood, we propose that the operational definition as presented may be useful in shaping a new framework for the complex immunological relationship between mother and fetus.

The equine placenta is of the non-invasive epitheliochorial type, with six intact cell layers separating maternal and fetal blood supplies. The principal interface between uterus and placenta is an interdigitation of endometrial epithelium with allantochorion trophoblast that forms characteristic microvilli (Allen, 1975). The trophoblast cells at this interface do not express either MHC class I or MHC class II antigens (Donaldson et al., 1990, 1992; Maher et al., 1996), and thus do not pose an immunological challenge to the mother. However, equids also have a minor subpopulation of invasive trophoblasts that do express $\mathrm{MHC}$ molecules as they migrate into the endometrium to form the endometrial cups (Fig. 1). The invasive equine chorionic girdle trophoblasts and the early endometrial cup trophoblast cells express very high levels of polymorphic, paternal and maternal MHC class I antigens during a short window in early pregnancy between days 30 and 45 of gestation (Donaldson et al., 1992, 1994). The level of expression of these MHC class I antigens is similar to that found on lymphocytes and other antigen presenting cells of the immune system, 
Split immunological tolerance to trophoblast
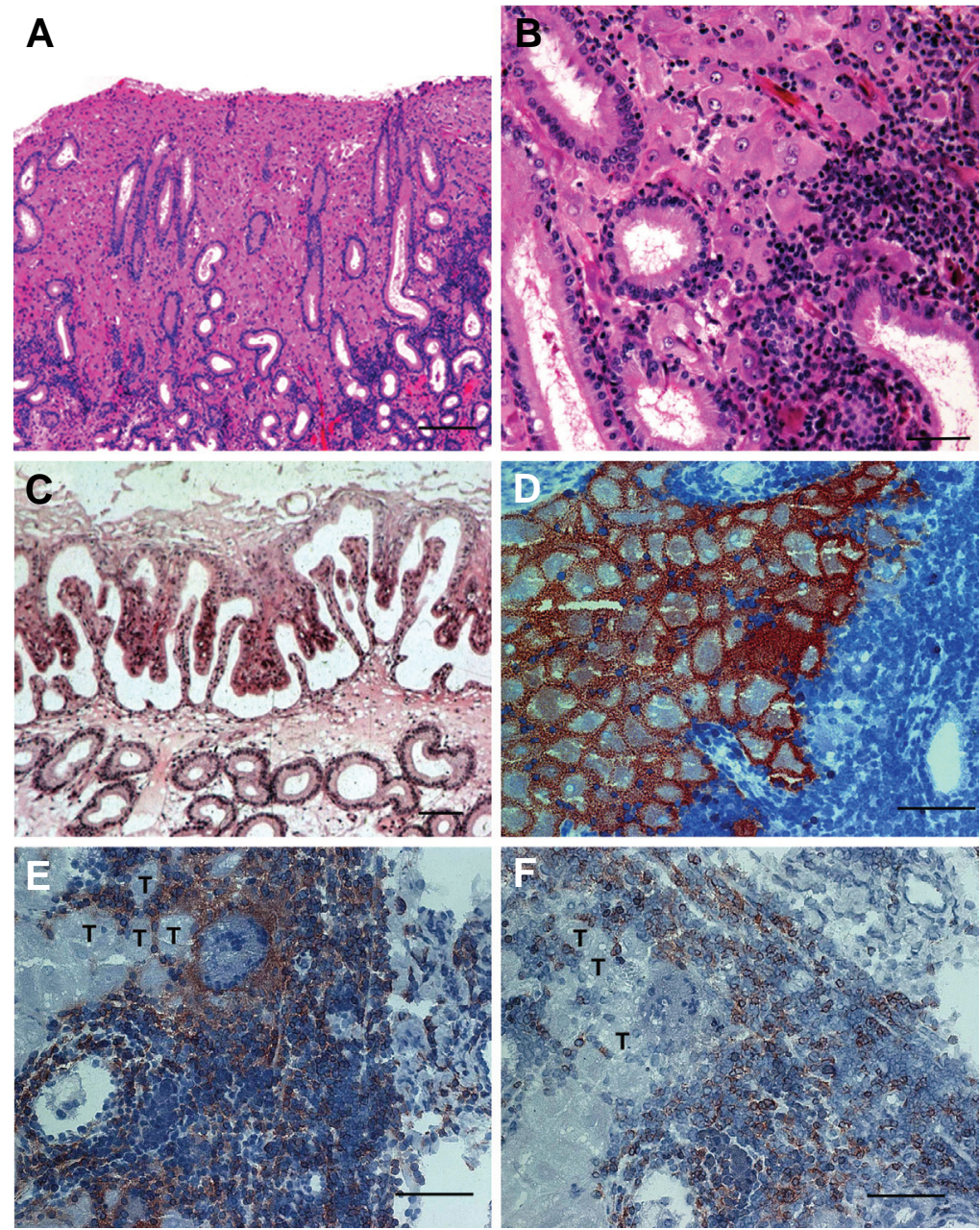

Fig. 2. Histological images of endometrial cups and endometrium from early equine pregnancy. (A-C) H\&E stained fixed sections. (A) Low power image of endometrial cup showing accumulations of maternal lymphocytes concentrated along the periphery of the cup. (B) High power image from (A) showing aggregations of maternal lymphocytes, endometrial glands, and large binucleate pale staining endometrial cup trophoblast cells. (C) Endometrium - allantochorion border. Note the lack of lymphocyte accumulations at the placental-uterine interface. (D-F) Immunohistochemical labeling of frozen sections of endometrial cups. (D) Monoclonal antibody 102.1 (anti-horse trophoblast), showing distinct margin of the endometrial cup. Anti-horse CD4 antibody (E) and anti-horse CD8 antibody (F) labeling the respective $T$ cell subsets surrounding endometrial cup trophoblasts (T). Size bar indicates $100 \mu \mathrm{m}$ in all panels except A $(400 \mu \mathrm{m})$. All specimens are from day 43-46 of gestation.

and about 10 fold higher than the level found on other somatic tissues (Bacon et al., 2002).

Virtually $100 \%$ of mares carrying MHC incompatible pregnancies mount strong primary or secondary antibody responses to the foreign paternally inherited MHC class I antigens of their fetuses, and the timing of this response is consistent with induction by the MHC class I positive chorionic girdle and early endometrial cup cells (Antczak et al., 1982, 1984). Transplantation of allogeneic trophoblast has demonstrated that the chorionic girdle cells are capable of producing this immunological sensitization on their own (Adams \& Antczak, 2001; de Mestre etal., 2008). These observations demonstrate conclusively that the $B$ cell compartment of the pregnant mare's immune system is not tolerized, and suggests that T cells required to 'help' B cells produce antibody may also be activated during pregnancy.

At the level of the fetal-maternal interface, the invading $\mathrm{MHC}$ class I positive trophoblasts of the early endometrial cups attract a striking accumulation of maternal CD4+ and CD8+ T lymphocytes around them, but this apparent cellular immune response does not result in immediate destruction of the endometrial cups (Fig. 2) (Grünig et al., 1995). Once the endometrial cups are fully formed, the binucleate, equine chorionic gonadotrophin (eCG) secreting trophoblast cells of the cups down regulate expression of their MHC genes (Donaldson et al., 1992; Maher et al., 1996). Paradoxically, the local lymphocyte-dominated response appears to eventually result in the destruction of the endometrial cups, which is usually complete between days 80 and 120 of the mare's 335 day gestation (Allen, 1979).

Earlier work from our group identified a decrease in the capacity of peripheral blood lymphocytes from pregnant mares and jenny donkeys to develop into alloreactive cytotoxic lymphocytes after in vitro culture with irradiated lymphocytes from MHC incompatible mating stallions or jack donkeys (Baker et al., 1999). Thus, the peripheral cytotoxic $T$ cell $(C T L)$ response to paternal alloantigens seems to be impaired during normal equine pregnancy, while the $B$ cell response remains intact. We hypothesized that other systemic differences might exist between peripheral lymphocytes of pregnant and non-pregnant mares, and we therefore examined several variables for this study. We also tested a second hypothesis, that immune reactivity would differ between peripheral and local immune compartments, and here we compared tissue lymphocytes from the endometrium and endometrial cups with peripheral blood lymphocytes obtained on the same day of gestation from pregnant mares.

\section{Results}

Prior work had established that lymphocytes from pregnant mares show a decrease in capacity to generate cytotoxic $T$ cells towards the mating stallion compared to the non-pregnant state (Baker et al., 1999). In the first part of this study, selected additional aspects of the immune status of a cohort of 15 mares were compared during pregnancy and in the non-pregnant state. Jugular blood samples were obtained prior to the establishment of pregnancy, and again at about 30 days of gestation, a stage in which the decrease in CTL reactivity had been readily detected. The composition of the lymphocyte populations, cytokine profiles, and FOXP3 expression were determined in PBMC samples from the mares. All of the mares were mated to produce MHC incompatible conceptuses, using one of two MHC homozygous stallions (Table 1).

\section{Peripheral CD4 and CD8 populations in early pregnancy in the mare}

Flow cytometry with equine specific monoclonal antibodies was used to determine the percentage of peripheral blood lymphocytes expressing the T lymphocyte subset markers CD4 or 
TABLE 1

\section{MARES USED FOR COMPARISON OF IMMUNE STATUS IN PERIPHERAL BLOOD IN THE PREGNANT AND NON-PREGNANT STATES}

\begin{tabular}{|c|c|c|c|}
\hline Mare ID & Mare MHC haplotype\# & $\begin{array}{l}\text { Mating stallion } \\
\text { MHC haplotype\# }\end{array}$ & $\begin{array}{c}\text { Gestational day of PBMC } \\
\text { isolation }\end{array}$ \\
\hline 3845 & A5 / W16 & $\mathrm{A} 2$ / A2 & 31 \\
\hline 3837 & A8 /? & A2 / A2 & 29 \\
\hline 3157 & A3 / A3 & $\mathrm{A} 2$ / A2 & 30 \\
\hline 3638 & A7 /? & А3 / A3 & 30 \\
\hline 2885 & АЗ / АЗ & A2 / A2 & 31 \\
\hline 3419 & A2 / A5 & АЗ / $\mathrm{A} 3$ & 32 \\
\hline 3099 & A2 / A2 & $\mathrm{A} 3 / \mathrm{A} 3$ & 29 \\
\hline 3725 & A2 /? & АЗ / A3 & 31 \\
\hline 3641 & A3 / A19 & A2 / A2 & 31 \\
\hline 3820 & $\mathrm{~A} 19 / \mathrm{W} 16$ & $\mathrm{~A} 2$ / A2 & 32 \\
\hline 3354 & АЗ / A3 & $\mathrm{A} 2$ / A2 & 29 \\
\hline 3640 & А $3 / ?$ & A2 / A2 & 30 \\
\hline 3492 & $\mathrm{~A} 2 / ?$ & A3 / A3 & 31 \\
\hline 2998 & $? / ?$ & $\mathrm{~A} 3 / \mathrm{A} 3$ & 30 \\
\hline 3821 & A6 / W16 & $\mathrm{A} 3 / \mathrm{A} 3$ & 30 \\
\hline
\end{tabular}

\# MHC types of the horses were determined by a standard lymphocyte microcytotoxicity assay using alloantisera to Equine Leukocyte Antigen (ELA) markers that had been validated in international workshops, as described in the Materials and Methods. Equine MHC haplotypes are designated by the letter $\mathrm{A}$ followed by a number. The two mating stallions were purpose-bred MHC homozygotes from the Cornell experimental herd. Mares known to be MHC homozygotes are indicated with the same nomenclature used for the stallions. Mares with one or two "?" designations are either homozygotes for the single defined haplotype they carry, or heterozygotes carrying a haplotype (or two) for which no identifying antisera are available. The undetermined MHC haplotypes were not ELA-A2 or ELA-A3.
CD8 (Fig. 3). The average percentage of CD4+ lymphocytes was $56 \%$ in the non-pregnant state, and $54 \%$ in the pregnant state, and ranged between $40 \%$ and $70 \%$ of total lymphocytes.

The average percentage of CD8+ lymphocytes was $16.5 \%$ in the non-pregnant state, and $17 \%$ in the pregnant state, and ranged between $9 \%$ and $23 \%$ of total lymphocytes. There were no significant changes in the percentages of CD4+ lymphocytes or CD8+ lymphocytes between the pregnant and non-pregnant states. However, there was a trend towards decreasing CD4+ lymphocytes and increasing CD8+ lymphocytes in the mares during pregnancy. Thus, the ratio of CD4:CD8 was significantly reduced in pregnancy compared to the non-pregnant state.

\section{Changes in cytokine producing lymphocytes in early equine pregnancy}

The percentages of peripheral blood lymphocytes expressing IFNG or IL4 were determined using newly characterized monoclonal antibodies reactive with these equine cytokines (Fig. 4). In the population of mares under study, the percentage of IFNG+ lymphocytes varied considerably in both the non-pregnant and pregnant groups. In the mares sampled when pregnant, there was a trend towards increases in the percentages of IFNG+ cells in the overall lymphocyte population (Fig. 4A) and in the sub-population of CD8+ T cells (Fig. 4B), although these changes were not statistically significant. However, there was a modest increase in the percentage of IL4+ cells (Fig. 4C) and a decrease in the IFNG:IL4 ratio (Fig. 4D) in the overall lymphocyte population in the mares during pregnancy.
A

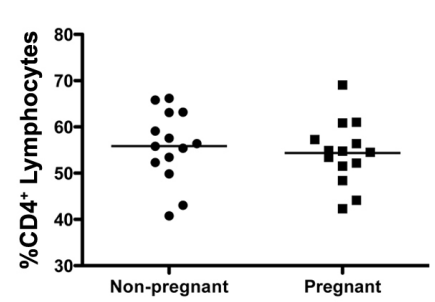

C

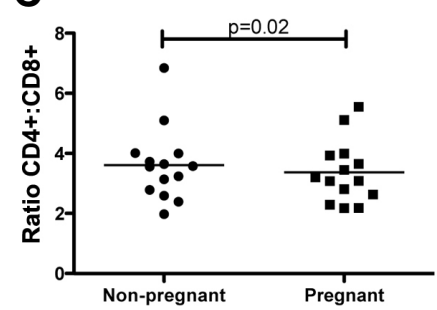

B

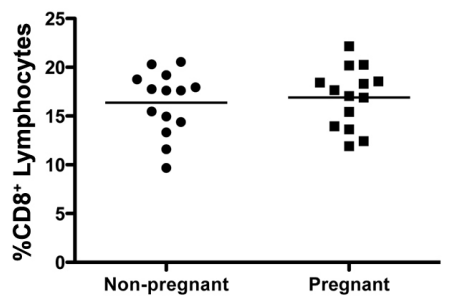

A

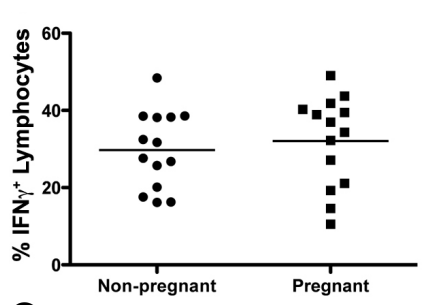

C

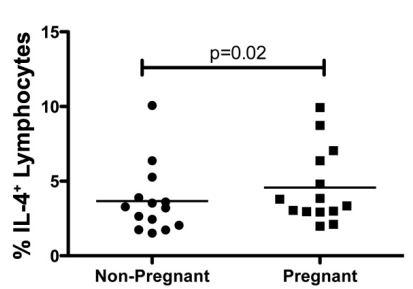

B

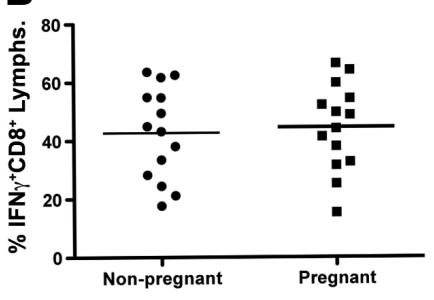

D

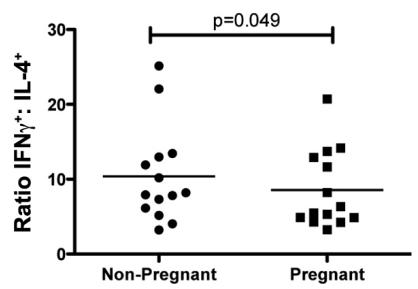

Fig. 3 (Left). Cell surface marker expression by peripheral lymphocytes from mares during the pregnant and non-pregnant states. Flow cytometric analysis of paired samples of PBMC isolated during early pregnancy (days 29-33) or the luteal phase of estrous ( $n=15$ ). Cells were labeled with monoclonal antibodies to cell surface markers as described in Materials and Methods. (A) Percentage of peripheral lymphocytes expressing CD4. (B) Percentage of peripheral lymphocytes expressing CD8. (C) The ratio of CD4+:CD8+ peripheral lymphocytes.

Fig. 4 (Right). Cytokine expression by peripheral lymphocytes from mares during the pregnant and non-pregnant states. Flow cytometric analysis of IFNG and IL4 expression of paired samples of PBMC isolated during early pregnancy (days 29-33) or the luteal phase of estrous (n=15). Cells were stimulated then stained for intracellular cytokines and cell surface markers as described in Materials and Methods. (A) Percentage of peripheral lymphocytes expressing IFNG. (B) Percentage of CD8+ peripheral lymphocytes expressing IFNG. (C) Percentage of peripheral lymphocytes expressing IL4. (D) The ratio of IFNG+:IL4+ peripheral lymphocytes. 


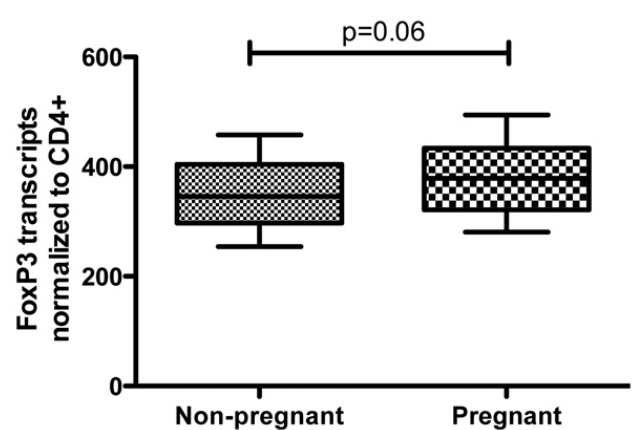

Fig. 5 (Left). FOXP3 expression by peripheral lymphocytes from mares during pregnant and non-pregnant states. Quantitative realtime PCR analysis of FOXP3 expression in paired samples of cDNA from PBMC isolated during early pregnancy (days 29-33) or the luteal phase of estrous ( $n=15)$. Absolute numbers of FOXP3 + transcripts were determined and normalized to a housekeeper gene and the number of CD4+ lymphocytes as described in Materials and Methods.

Fig. 6. (Right). Cell surface marker expression of lymphocytes isolated from the equine maternal-fetal interface at day 43-46 of pregnancy. (A) Flow cytometric analysis of lymphocytes isolated from endometrial cups (ECL): $C D 4 n=6, C D 8 n=6, C D 19 n=4$; pregnant endometrium (ENDO. L): $n=5$; and PBMC: $n=6$. Cells were labeled for the cell surface markers CD4, CD8, and CD19 as described in Materials and Methods. Upper left panel shows a representative image of forward scatter (FSC) and side scatter (SSC) of ECL and the gate set to analyze the lymphocyte population. A similarly positioned gate was set to analyze ENDO. $L$ and PBMC. (B) The ratio of CD4+:CD8+ lymphocytes at the site of endometrial cups (ECL), in pregnant endometrium (ENDO. L.) and in the periphery (PBMC) $(n=6)$.

\section{FOXP3 expressing lymphocytes were unchanged during early equine pregnancy}

A quantitative RT-PCR assay was used to determine the number of transcripts of the immunoregulatory transcription factor FOXP3 in lymphocyte samples collected from mares in the pregnant and non-pregnant state (Fig. 5). The values were normalized to the percentage of CD4+ lymphocytes detected in the PBMC samples. There was a trend towards an increase in FOXP3 expression in the pregnant group, but the difference was not statistically significant.

\section{Phenotype of lymphocytes at the equine fetal-maternal inter- face}

The second part of this study compared immune reactivity of equine peripheral blood lymphocytes with tissue lymphocyte populations from the endometrium in samples obtained at necropsy in a group of six pregnant mares between days 43 and 46 of gestation. The endometrial cup reaction is characterized by focal accumulations of CD4+ and CD8+ lymphocytes which are located both within and immediately surrounding the eCG secreting terminally differentiated invasive trophoblast cells. The endometrium located away from the endometrial cups contains only small numbers of leukocytes (Fig. 2C and Grünig et al., 1995). For these investigations we isolated cells from both the endometrial cups and the endometrium. The endometrial cups represent only a small portion of the total endometrial surface (Fig. 1B). On average, 9 grams of endometrial cup tissue was recovered from each uterus. The endometrial cups were dissected from the
A
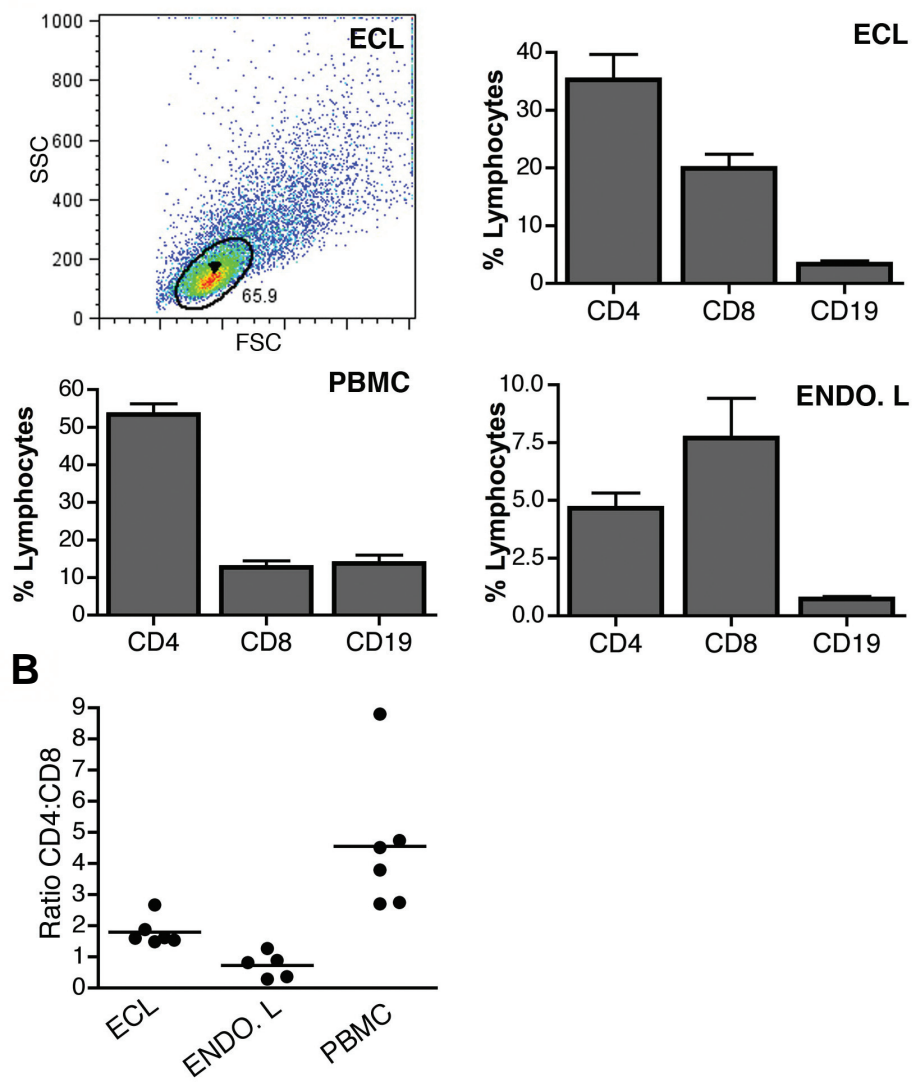

endometrium by trimming away all but $2-3 \mathrm{~mm}$ of adjacent endometrial tissue, and subjected to enzyme mediated digestion. This yielded an average of 38 million cells for analysis. In contrast, about 30 grams of endometrium was typically used for cell isolation, resulting in recovery of only about 10 million total cells.

In order to determine the phenotype of the cells isolated from endometrial tissues, we performed flow cytometric analysis with equine specific monoclonal antibodies. Using gates set for lymphocytes, the percentages of cells expressing equine CD4, CD8, and the B-cell marker CD19 were determined and compared to values obtained from peripheral blood samples taken from the mares on the day of necropsy. The cells isolated from the endometrial cups were comprised of $35 \% \mathrm{CD} 4+$ lymphocytes, $20 \%$ CD $8+$ lymphocytes, and only about $3 \%$ B cells. In the endometrial cell population $4.7 \%$ of the cells were CD4+, with $7.7 \%$ positive for $\mathrm{CD} 8$, and less than $1 \% \mathrm{~B}$ cells. The cells isolated from endometrial cups and endometrium contained variable numbers of contaminating non-lymphoid cells. The PBMC populations had an average of $53 \%$ CD4+ lymphocytes, $12 \%$ CD $8+$ lymphocytes, and $14 \% \mathrm{~B}$ cells. Although the ratios of CD4+:CD8+ cells appeared different in the three groups, because of high variance in the PBMC group the differences were not statistically significant (Fig. 6B).

\section{Cytokine expression by lymphocytes at the equine fetal- maternal interface}

The percentages of lymphocytes expressing IFNG or IL4 in peripheral blood and in the endometrial cup lymphocyte popula- 
A
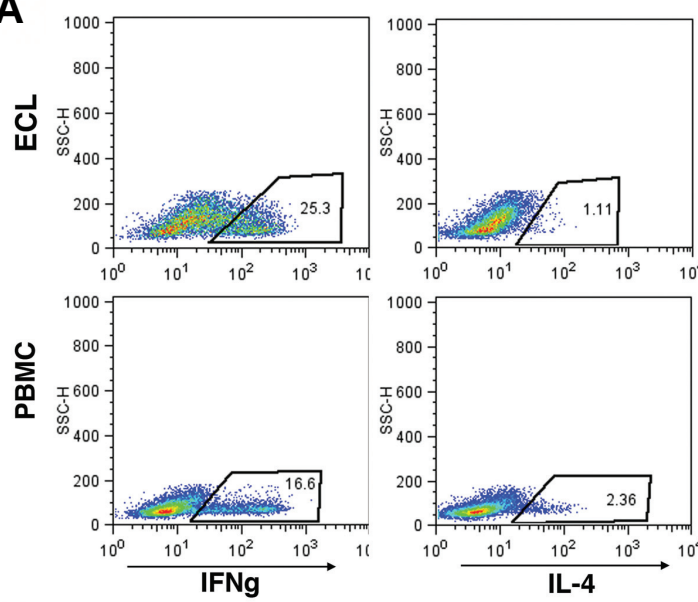

B

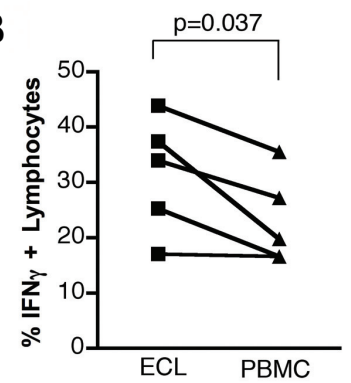

C
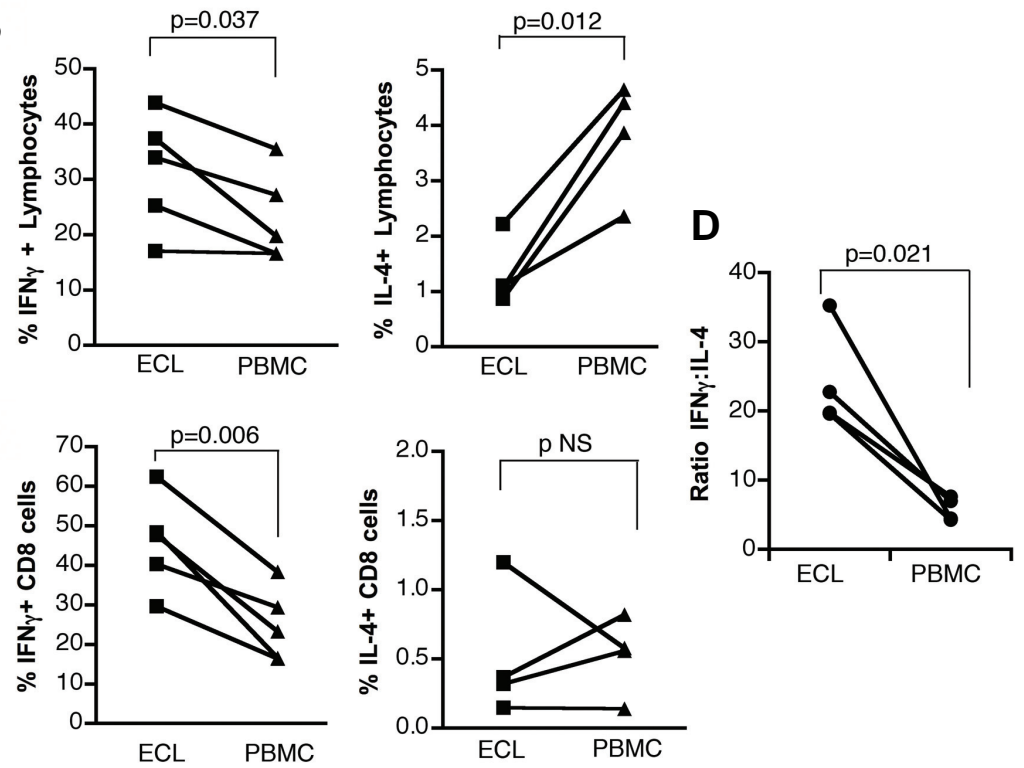

Fig. 7. Cytokine expression by lymphocytes at the equine maternal-fetal interface. Flow cytometric analysis of IFNG and IL4 expression by paired samples of endometrial cup lymphocytes (ECL) and PBMC. Cells were stimulated ex vivo for 4 hours with PMA and $1 O$ in the presence of Brefeldin A. (A) Images of representative dot plots of ECL and PBMC cells isolated from one mare following labeling with IFNG (left panel), IL4 (middle panel) or an isotype control antibody (right panel). Lymphocyte gates were set to analyze cytokine expression by the lymphocyte population. (B) Percentage of lymphocytes expressing IFNG ( $n=5$ mares) or IL4 ( $n=4$ mares). (C) Percentage of CD8+ lymphocytes surrounding the endometrial cups (ECL) or in the periphery (PBMC) producing IFNG $(n=5)$ or IL4- $(n=4)$. Lymphocyte and CD8 gates were set to analyze the IFNG and IL4 populations. (D) The ratio of IFNG+:IL4+ lymphocytes at the site of endometrial cups (ECL) and in the periphery (PBMC) $(n=4)$. lymphocytes around the endometrial cups compared to PBMC (Fig. 7 C). Finally, these changes resulted in an approximately 3 -fold increase in the ratio of IFNG to IL4 in the endometrial cups lymphocytes compared to lymphocytes from peripheral blood (Fig. 7 D).

\section{Evidence for regulatory $T$ cells at the equine fetal- maternal interface}

A combination of flow cytometry and quantitative RTPCR assays were used to compare the expression of FOXP3 protein and messenger RNA in paired samples of CD4+ lymphocytes from the endometrial cups and peripheral blood of pregnant mares (Fig. 8). In all cases the expression of FOXP3 was higher in the local lymphocyte population from the uterus compared to peripheral blood, and the levels in the grouped samples did not overlap. There was a 3-fold increase in FOXP3 mRNA expression, which correlated well with the 3.2fold increase in FOXP3+ cells in the same population. It is likely that these CD4+, FOXP3+ lymphocytes represent equine regulatory $\mathrm{T}$ cells.

\section{Discussion}

This study addressed aspects of two unresolved issues in reproductive immunology. First is the question of systemic changes in maternal immune reactivity during pregnancy, and second is the relevance of those changes in the periphery to local immunological events at the fetal-maternal interface. The pregnant mare is a good subject in which to address these issues because the horse provides the opportunity for examination of peripheral immune responses before and during pregnancy in the same individual, and also for direct comparison of peripheral and local responses in the uterus. In the mare there is an early, robust, and consistent antibody response to the fetus (Antczak et al., 1984), and evidence for diminished capacity to generate cytotoxic lymphocytes reactive against paternal MHC class I antigens during pregnancy (Baker et al., 1999). In a large, well-controlled cohort of mares sampled before and during pregnancy, we detected only slight changes in the character and composition of peripheral blood lymphocytes. In contrast, we measured significant differences in the same variables when comparing the periphery with the endometrium in pregnant mares.

Many physiologic changes accompany the transition from the non-pregnant to the pregnant state, including alterations in cells and molecules of the tion were determined in samples paired from the same donor mares (Fig. 7). In every comparison between peripheral blood and endometrial cups, the percentage of IFNG+ lymphocytes was increased and the percentage of IL4+ lymphocytes was decreased in the local compartment in the uterus (Fig. $7 \mathrm{~A}$ and $\mathrm{B}$ ). There was a $36 \%$ increase in IFNG+ lymphocytes and a $65 \%$ decrease in IL4+ lymphocytes surrounding the endometrial cups (Fig. 7B). In the CD8+ subpopulation, this change was accentuated for IFNG, where there was an $84 \%$ increase in IFNG+ immune system. These changes may reflect specific maternal immunological recognition of the conceptus (Antczak, 1989), a generalized shift in the character of the maternal immune system that favors the development of the semi-allogeneic fetus (Baker et al., 1999; Krishnan et al., 1996a; PejcicKarapetrovic et al., 2007), or specific tolerance to paternal and / or fetal alloantigens (Tafuri et al., 1995; Jiang \& Vacchio, 1998; Ait-Azzouzene et al., 1998, 2001; Erlebacher et al., 2007). It is in this context that the term 'split tolerance to 
A

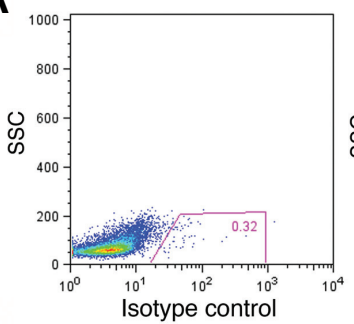

B

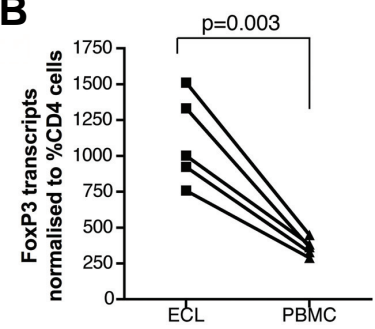

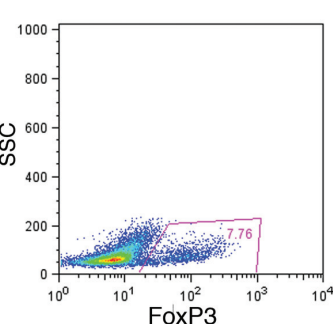

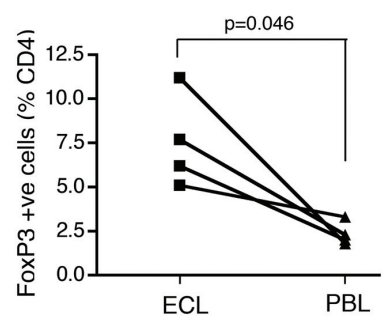

Fig. 8. Tregs are increased at the equine maternalfetal interface. (A) Flow cytometric analysis of FOXP3 expression in paired samples of lymphocytes isolated from endometrial cups (ECL) and PBL ( $n=4$ mares). Lymphocyte and CD4 gates were set to analyze the FOXP3 population. Representative dot plots of ECL used to calculate the FOXP3 population are shown. (B) FOXP3 mRNA expression in paired samples of lymphocytes isolated from endometrial cups (ECL) and PBMC ( $n=5$ mares).

trophoblast' offers a novel framework for defining the complex immunological relationship between mother and fetus.

At the systemic level represented by the circulating cells of the immune system, there is evidence for changes during pregnancy in several species in the percentages of lymphocytes producing specific cytokines (Faas et al., 2005), in the ratios and numbers of lymphocytes and lymphocyte subsets (Faas et al., 2005), and in the numbers of regulatory T cells (Aluvihare et al., 2004; Somerset et al., 2004; Saito et al., 2005; Oliviera \& Hansen, 2008). In humans, it has been reported that in peripheral blood the percentage of lymphocytes producing IFNG decreases, and the percentage of lymphocytes producing IL4 does not change. In contrast, in rats the percentage of IFNG and IL4 producing lymphocytes during pregnancy did not change, although the total number of circulating lymphocytes was reduced (Faas et al., 2005). In cattle, at day 33-34 of pregnancy no changes in the numbers of CD4, CD8, or gamma-delta T cells were detected compared to the non-pregnant state, but the percentage of CD4+ $\mathrm{T}$ cells that also expressed CD25+ (presumed Tregs) was increased (Oliveira and Hansen, 2008). The changes measured in one species are not always identified in studies in other species, but overall, the research cited supports the generality of peripheral immune system alterations during pregnancy. One of the most consistent changes noted in these studies is the increase in regulatory $T$ cells in peripheral blood during pregnancy.

The immune status differences we measured in the periphery between the pregnant and non-pregnant state in mares were not dramatic. Thus, the ratios of CD4+:CD8+ T cells, the percentages of T cells expressing either IFNG or IL4, and the number of FOXP3 transcripts in lymphocytes were not drastically altered during pregnancy. Taken together, our results have not identified immunological pathways that might account for either the decreased capacity of mares to mount CTL responses against MHC class I antigens of the mating stallions (Baker et al., 1999), or the strong antipaternal alloantibody responses characteristic of MHC incompatible pregnancies in the mare (Antczak et al., 1984). These results reinforce the idea that different components of the immune system are affected differentially during pregnancy.

At the local level of the uterus, there is increasing evidence for the accumulation in the endometrium of lymphocytes with the CD4+CD25+FOXP3+ phenotype of Tregs in mice (Aluvihare etal., 2004; Zenclussen et al., 2006) and in humans (Tilburgs et al., 2006; Sasaki et al., 2007). This is consistent with our findings in the mare reported here. We measured increased numbers of FOXP3+CD4+ T cells around the endometrial cups compared to peripheral blood (Fig. 8). In the lymphocytes recovered from the endometrial cups, there was also a marked increase in IFNG + cells in the total population and in the CD8+ subpopulation and a decrease in lymphocytes expressing IL4 (Fig. 7). Our results are in agreement with a recent study that reported high levels of expression of IFNG and undetectable levels of IL4 by human decidual CD8+ lymphocytes (Scaife et al., 2006). Interestingly, our findings, as well as those of Scaife and colleagues in human pregnancy, are in conflict to the traditional dogma that pregnancy is associated with a decrease in the ratio of Th1:Th2 cytokines. Again this highlights the important differences that exist between local and peripheral compartments of the immune system during pregnancy, and furthermore suggests that the cytokine milieu during pregnancy is more complex than previously reported.

The increase in IFNG+ lymphocytes at the fetal-maternal interface may be related mechanistically to the increase in FOXP3. It has been shown that IFNG conditions the development of Tregs that can mediate allograft acceptance in mice (Feng et al., 2008). Five of the six pregnant mares we studied carried MHC incompatible conceptuses, and the sixth carried an MHC compatible conceptus. Previous studies demonstrated that the lymphocyte accumulations around the endometrial cups are not diminished in MHC compatible pregnancies (Allen et al., 1984), and the results presented here suggest that the lymphocyte, cytokine, and FOXP3 profiles are also similar to those of $\mathrm{MHC}$ incompatible pregnancies. To our knowledge, our results represent the first description of regulatory $\mathrm{T}$ cells in the horse.

The immunological events in equine pregnancy are consistent with a state of split tolerance to trophoblast. The early, robust alloantibody response in mares is induced locally in the uterus by the invasion of the chorionic girdle cells bearing high levels of polymorphic cell surface MHC class I antigens (Antczak et al., 1984; Donaldson et al., 1990, 1992). Mares can generate very high secondary antibody responses in early pregnancy after prior priming in the periphery by skin grafting (Adams et al., 2007), and chorionic girdle cells transplanted to sites outside the uterus in non-pregnant mares can stimulate alloantibody responses without any additional components of the conceptus (Adams and Antczak, 2001; de Mestre et al., 2008). These results all point to the ability of the invasive trophoblast to induce a local $B$ cell (antibody) response to the fetus in the endometrium.

The involvement of the T cell arm of the immune system in the response to invading trophoblast seems much more complex. The invasion of the endometrium by the chorionic girdle is accompanied by the accumulation of large numbers of CD4+ and CD8+ T lymphocytes around the base of the cups (Fig. 2 and Grünig etal., 1995). An early interpretation of this endometrial cup reaction was that it represented $\mathrm{T}$ cell mediated recognition that 
would result in destruction of the endometrial cup trophoblast cells (Allen 1975, 1979). The discovery that the chorionic girdle expresses high levels of polymorphic paternal MHC class I antigens, while the allantochorion trophoblast does not (Donaldson et al., 1990), suggested a reason why the uterine lymphocyte accumulations of early equine pregnancy were restricted to the area around the endometrial cups, and not the endometriumallantochorion border.

This solution, however, posed another question. How do the endometrial cup trophoblasts avoid destruction by the surrounding $T$ cells during their normal $50-70$ day lifespan? Although the invading chorionic girdle and early endometrial cups do express polymorphic $\mathrm{MHC}$ class I antigens, these molecules are lost from the cell surface as the cup trophoblast cells mature into their, binucleate, eCG secreting, terminally differentiated state (Donaldson etal., 1992, Maher etal., 1996). This down regulation of MHC class I genes and molecules in the cup cells may extend their lifespan; classical alloreactive cytotoxic T lymphocytes should be unable to kill the mature, MHC class I negative endometrial cup trophoblasts. This would enable the cups to safely secrete the eCG that is necessary to induce the secondary corpora lutea that provide the progesterone needed to maintain equine pregnancy until approximately day 100 , when the placenta itself develops the capacity to produce progesterone. The mechanisms that result in the death of the endometrial cup trophoblasts remain elusive: are they killed by an as yet uncharacterized immune response, perhaps mediated by NK cells, or do they self-destruct, having outlived their usefulness?

Equally intriguing are the mechanisms that prevent $\mathrm{T}$ cell mediated destruction of the day 38 - 45 chorionic girdle and early endometrial cup trophoblasts that express MHC class I antigens. In vitro studies demonstrated that equine $\mathrm{MHC}$ class I chorionic girdle trophoblasts are susceptible to killing by alloreactive cytotoxic lymphocytes, when the responding lymphocytes are obtained from non-pregnant horses (Baker et al., 2000). Longitudinal studies of the leukocyte response to the endometrial cups revealed that the numbers of $\mathrm{T}$ lymphocytes around the cups diminish as the cups mature, and then increase again towards the end of the normal lifespan of the cups (Grünig et al., 1995). This was interpreted as evidence for immunoregulatory events aimed at the $T$ cells surrounding the cups. The molecular and cellular phenotyping studies of endometrial cup lymphocytes reported here strengthen that hypothesis. It may be that CD4+FOXP3+ regulatory T cells in the mare's uterus are recruited to the site of chorionic girdle invasion, where they could act to prevent the premature destruction of the endometrial cups before the cup trophoblasts down regulate their $\mathrm{MHC}$ class I antigens and thus become invisible to cytotoxic T cells. Co-cultures of invasive trophoblast cells and peripheral lymphocytes resulted in diminished lymphocyte proliferation to mitogenic stimuli (Flaminio and Antczak, 2005). That model system may be an in vitro correlate of mechanisms operating in and around the endometrial cups.

It is not known if the local regulatory $T$ cells of the endometrial cups are related to the peripheral decrease in CTL capacity in the pregnant mare, but it seems unlikely, because the peripheral lymphocytes of pregnant mares had the same level of FOXP3 expression as lymphocytes from the mares when not pregnant. The systemic, strong antibody responses of equine pregnancy highlight the robust, intact, B cell compartment of the mare during pregnancy and the ability of the mare's immune system to generate serological responses to antigenic stimulation by the conceptus within the uterus. In contrast, the evidence for different peripheral and local regulation of aspects of T cell immunity in the pregnant mare emphasizes the split nature of tolerogenic mechanisms protecting the equine fetus from destruction by the maternal immune system.

\section{Materials \& Methods}

\section{Animals}

Adult horses of mixed breeds and ages were used in this research (Tables 1 and 2). Horses were maintained at the Baker Institute for Animal Health, Cornell University. Animal care was performed in accordance with the guidelines set forth by the Institutional Animal Care and Use Committee of Cornell University. Pregnancies were established as previously described (Adams and Antczak, 2001). Major Histocompatibility Complex haplotypes were assigned to the horses based on results of tissue typing using a panel of well-characterized alloantisera that had been validated in international workshops (Lazary et al., 1988).

\section{Tissue and cell preparation}

Heparinized samples of venous jugular blood were collected from mares during diestrus, at day $31 \pm 2$ of pregnancy, or immediately prior to euthanasia, as indicated. Peripheral blood mononuclear cells (PBMC) and peripheral blood lymphocytes (PBL) were isolated using methods described previously (Antczak etal., 1982; Wagner etal., 2008). Endometrial cup lymphocytes (ECL) and endometrial lymphocytes (ENDOL) were isolated using an adaptation of a previously described method for human endometrial lymphocytes (Flynn et al., 1999). Equine uteri were obtained surgically immediately following euthanasia of six mares confirmed by transrectal ultrasonography to be day 43 to day 46 pregnant. One mare was pregnant with twins. The tissue was placed immediately into Hanks Balanced salt solution (Gibco Invitrogen Corp, Carlsbad, CA) supplemented with $5 \%$ fetal calf serum (FCS, Hyclone, Logan, Utah). The endometrial cups and approximately $2-3 \mathrm{~mm}$ of adjacent endometrium were dissected free of the remaining uterine tissues. The average weight of the endometrial cup tissue was nine grams. Endometrial tissue was collected from a site distal to the endometrial cups. Tissue was minced using scissors, then placed into a enzyme solution containing RPMI medium with $25 \mathrm{mM}$ Hepes (Gibco Invitrogen Corp), 1\% FCS, 1\% (w/v) bovine serum albumin (Sigma, St Louis, MO), and $35 \mathrm{U} / \mathrm{ml}$ DNase (Sigma) and incubated at 37 degrees. After 10 minutes, collagenase (Sigma) was added to the enzyme solution at a concentration of $200 \mathrm{U} /$ $\mathrm{ml}$ and the tissue incubated at 37 degrees for an additional 20 minutes. Tissue was then passed through $100 \mu \mathrm{m}$ and $40 \mu \mathrm{m}$ cell strainers (BD Biosciences, San Jose, CA). The cell suspension was then washed in

TABLE 2

\section{MARES USED FOR ENDOMETRIAL CUP LYMPHOCYTE ISOLATION AND CHARACTERIZATION}

\begin{tabular}{ccccc} 
Mare ID & $\begin{array}{c}\text { Mare MHC } \\
\text { haplotype\# }\end{array}$ & $\begin{array}{c}\text { Mating stallion } \\
\text { MHC haplotype\# }\end{array}$ & $\begin{array}{c}\text { Gestational day of } \\
\text { PBMC and ECL* } \\
\text { isolation }\end{array}$ & $\begin{array}{c}\text { Number of cells isolated } \\
\text { from endometrial cups }\end{array}$ \\
\hline 3382 & A10 /? & A3 / A3 & 46 & $60.5 \times 10^{6}$ \\
3549 & A19 /? & A3 / A3 & 43 & $26.0 \times 10^{6}$ \\
3842 & A5 / A19 & A2 / A2 & 45 & $16.7 \times 10^{6}$ \\
3845 & A5 / W16 & A3 / A3 & 44 & $6.2 \times 10^{6}$ \\
3837 & A8 /? & A3 / A3 & 44 & $26.5 \times 10^{6}$ \\
3901 & A2 / A19 & A2 / A2 & 45 & $25.5 \times 10^{6}$ \\
\hline
\end{tabular}

\# For a description of the MHC typing methods and assignments, see footnote to Table 1. * ECL: Endometrial Cup Lymphocyte. 
phosphate buffered saline (PBS) $/ 0.5 \%$ FCS. Cell suspensions were subjected to fractionation using Ficoll-Paque Plus (GE Healthcare, Piscataway, NJ). Lymphocyte enriched cell suspensions were then washed twice in PBS $/ 0.5 \%$ FCS. Viability of isolated cells was confirmed using trypan blue exclusion, and found to be greater than $80-90 \%$ for all samples. The total number of cells isolated from endometrial cups ranged from 1.1-3.6 $\times 10^{6} \mathrm{cells} / \mathrm{g}$ of tissue (Table 2 ).

\section{Cell culture and fluorescent labeling of cells and flow cytometry}

$E C L$, ENDO $L$ and PBMC were either fixed in $2 \%$ paraformaldehyde (Sigma) or stimulated with $25 \mathrm{ng} / \mathrm{ml}$ phorbol 12-myristate 13-acetate (PMA) and $1 \mu \mathrm{M}$ ionomycin (IO) in the presence of $10 \mu \mathrm{g} / \mathrm{ml}$ brefeldin A as previously described (Wagner et al., 2008). After 4 hours in culture, the stimulated cells were washed in PBS and fixed. Cells were labeled with monoclonal antibodies to equine cell surface markers CD4 (HB61A, VMRD, Pullman, WA), CD8 (CVS8, Lunn et al., 1998) and CD19 (CZ2.1, Lunn et al., 1998). Cytokine staining was performed using anti-bovine interferon gamma (IFNG) (MorphoSys, AbD Serotec, Oxford, UK) and anti-equine interleukin 4 (IL4) as previously described (Wagner et al., 2005, 2006). CD4, CD8, and IL4 antibodies were conjugated to Alexa dyes (A647 or A488) and anti-bovine IFNG was FITC conjugated by the supplier. For detection of intracellular expression of forkhead box P3 (FOXP3), ECL or PBL were isolated as described above. Freshly isolated cells were labeled with a directly conjugated antibody to equine CD4, followed by fixation, permeabilization, and labeling using a FOXP3 staining kit (eBioscience, San Diego, CA) and a cross reactive PE conjugated antibody to human FOXP3 (clone PCH101, eBioscience) or an IgG2a isotype control antibody (eBioscience) as per the manufacturer's instructions. Immunofluorescence flow cytometry was performed using a BD FACSCalibur (BD, Franklin Lakes, $\mathrm{NJ}$ ) and data analysis was performed using Flowjo software (Tree Star, Ashland, OR). For statistical comparison of the ECL and PBMC/PBL samples, and pregnant and nonpregnant PBMC, paired two-tailed Student's t tests or Wilcoxon rank sum tests were used with alpha error $=5 \%$ using GraphPad Prism software. For statistical comparison of the ECL, PBMC, and ENDO L samples, Krustal-Wallis or Tukey's one-way analysis of variance tests were used with an alpha error $=5 \%$ using GraphPad Prism software.

\section{RNA isolation, cDNA synthesis real time RT-PCR}

$E C L$ and PBMC were isolated as described above. RNA was isolated from $5 \times 10^{6}$ snap frozen cells, following homogenization by QIAshredder (Qiagen, Valencia, CA), using a RNeasy kit (Qiagen) as directed by the manufacturer. Five hundred nanograms of RNA was treated with DNase I (Invitrogen, Carlsbad, CA), then first strand cDNA synthesis was carried out using M-MLV Reverse Transcriptase (USB, Cleveland, $\mathrm{OH}$ ) as per the manufacturer's guidelines. SYBR Green (Applied Biosystems, Shelton, CO) real time RT-PCR reactions for amplification of equine FOXP3 or the housekeeper gene equine ubiquitin-conjugating enzyme E2D 2(UBE2D2) (de Mestre et al., 2003) mRNA were performed using a ABI PRISM 7700 or 7500 Fast sequence detector (PerkinElmer Life Sciences) in a total volume of $20 \mu \mathrm{l}$. Primers were designed over intron / exon boundaries to prevent amplification of genomic DNA. A dissociation curve was performed after each experiment to confirm that a single product was amplified. A standard curve was generated for FOXP3 and UBE2D2 genes using known copy numbers of a plasmid that contained the CDNA specific to the gene. Each FOXP3 sample was first normalized to 7500 copies of UBE2D2. The percentage of CD4+ lymphocytes in an aliquot of each sample was determined by flow cytometric analysis and FOXP3 mRNA expression was normalized to $50 \%$ CD4+ lymphocytes. The sequences of the oligonucleotides are:

FOXP3RT1: TGGCAAATGGTGTCTGCAA;

FOXP3RT2: $\quad$ GCGCTCTGCCCTTCTCATC;

UBC1: TGAAGAGAATCCACAAGGAATTGA;

UBC2: CAACAGGACCTGCTGAACACTG.

Changes in expression were analyzed for statistical significance by using a paired two-tailed Student's t test.

\section{Tissue immunohistochemistry}

Sections of endometrial cups and endometrium obtained at necropsy were fixed in buffered formaldehyde for conventional histology or transferred immediately to O.C.T. embedding compound (VWR Scientific Products, Willard, $\mathrm{OH}$ ), snap frozen in an isopentane bath in liquid nitrogen, and then stored at -80 degrees $\mathrm{C}$. Immunohistochemical labeling of frozen sections was performed as previously described (de Mestre et al., 2008).

\section{Acknowledgements}

We thank Scott Hoffay, Emily Benson, and Meleana Hinchman for assistance with horse breeding, and Don Miller and Christina Costa for technical assistance. This research was funded in part by the Dorothy Russell Havemeyer Foundation, Inc., the Harry M. Zweig Memorial Fund for Equine Research in New York State, and NIH grant R01-HD049545.

\section{References}

ADAMS, A. P. and ANTCZAK, D. F. (2001) Ectopic Transplantation of Equine Trophoblast. Biol Reprod 64: 753-763.

ADAMS, A.P., ORIOL, J.G., CAMPBELL, R.E., OPPENHEIM, Y.C., ALLEN, W.R., and ANTCZAK, D.F. (2007). The effect of skin allografting on the equine endometrial cup reaction. Theriogenology 68: 237-247.

AIT-AZZOUZENE, D., GENDRON, M.C., HOUDAYER, M., LANGKOPF, A., BURKI, K., NEMAZEE, D., and KANELLOPOULOS-LANGEVIN, C. (1998) Maternal B lymphocytes specific for paternal histocompatibility antigens are partially deleted during pregnancy. J. Immunol. 161: 2677-2683.

AIT-AZZOUZENE, D., CAUCHETEUX, S., TCHANG, F., WANTYGHEM, J., MOUTIER, R., LANGKOPF, A., GENDRON, M.C., and KANELLOPOULOSLANGEVIN, C. (2001) Transgenic major histocompatibility complex class I antigen expressed in mouse trophoblast affects maternal immature B cells. Biol. Reprod. 65: 337-344.

ALLEN, W.R. (1975) Immunological aspects of the equine endometrial cup reaction. In Immunobiology of the Trophoblast (Eds. Edwards, R.G., Howe, C. and Johnson, M.H.), Cambridge Univ. Press, Cambridge, pp. 217-253.

ALLEN, W.R. (1979) Maternal recognition of pregnancy and immunological implications of trophoblast endometrium interactions in equids. In Maternal Recog nition of Pregnancy. Ciba Foundation Series 64 (new series), Excerpta Medica, May 1979, pp. 323-352.

ALLEN, W.R., KYDD, J., MILLER, J., and ANTCZAK, D.F. (1984) Immunological studies on feto maternal relationships in equine pregnancy. Pp. 183-193, Chapter 11 of the Proceedings of the 38th Easter School, University of Nottingham, "Immunological Aspects of Reproduction in Mammals", D.B. Crighton, ed. Butterworths, London.

ALUVIHARE, V. R., KALLIKOURDIS, M., and BETZ, A. G. (2004) Regulatory T cells mediate maternal tolerance to the fetus. Nat. Immunol. 5: 266-271.

ANTCZAK, D.F., BRIGHT, S.M., REMICK, L.H., and BAUMAN, B.E. (1982) Lymphocyte alloantigens of the horse. 1. Serological and genetic studies. Tissue Antigens. 20: 172-187.

ANTCZAK, D.F., MILLER, J.M. and REMICK, L.H. (1984) Lymphocyte alloantigens of the horse. II. Antibodies to ELA antigens produced during equine pregnancy. J. Reprod. Immunol. 6: 283-297.

ANTCZAK, D.F. (1989) Maternal antibody responses in pregnancy. Curr. Opin. Immunol. 1: 1135-1140.

AVELINO, M.M., CAMPOS, D. JR., DO CARMO BARBOSA DE PARADA, J., and DE CASTRO, A.M. (2003) Pregnancy as a risk factor for acute toxoplasmosis seroconversion. Eur. J. Obstet. Gynecol. Reprod. Biol. 108: 19-24.

BACON, S.J., ELLIS, S.A., and ANTCZAK, D.F. (2002) Control of expression of Major Histocompatibility Complex genes in horse trophoblast. Biol. Repro. 66: 1612-1620.

BAKER, J. M., BAMFORD, A.I., and ANTCZAK, D.F. (1999) Modulation of allospecific CTL responses during pregnancy in equids: an immunological barrier to interspecies matings? J. Immunol. 162: 4496-4501. 
BAKER, J.M., BAMFORD, A.I., CARLSON, M.L., MCCULLOCH, C.E., and ANTCZAK, D.F. (2000) Equine trophoblast as an immunological target. J. Reprod. Fertility 56: 635-644.

BAKER, R.J., HERNANDEZ-FUENTES, M.P., BROOKES, P.A., and CHAUDHRY, A.N. (2001) Loss of Direct and Maintenance of Indirect Alloresponses in Renal Allograft Recipients: Implications for the Pathogenesis of Chronic Allograft Nephropathy. J. Immunol. 167: 7199-7206.

BILLINGTON, W.D. (2003) The immunological problem of pregnancy: 50 years with the hope of progress. A tribute to Peter Medawar. J. Reprod. Immunol. 60: 1-11.

BLOIS, S. M., ILARREGUI, J. M., TOMETTEN, M., GARCIA, M., ORSAL, A. S., CORDO-RUSSO, R., TOSCANO, M. A., BIANCO, G. A., KOBELT, P., HANDJISKI, B., TIRADO, I., MARKERT, U. R., KLAPP, B. F., POIRIER, F. SZEKERES-BARTHO, J., RABINOVICH, G. A. and ARCK, P. C. (2007) A pivotal role for galectin-1 in fetomaternal tolerance. Nat Med. 13: 1450-1457.

CAUCHETEUX, S.M., KANELLOPOULOS-LANGEVIN, C., and OJCIUS, D.M. (2003) At the innate frontiers between mother and fetus: linking abortion with complement activation. Immunity 18: 169-172.

CHAN, W.F., RAZAVY, H., LUO, B., SHAPIRO, A.M. and ANDERSON, C.C. (2008) Development of either split tolerance or robust tolerance along with humoral tolerance to donor and third-party alloantigens in nonmyeloablative mixed chimeras. J Immunol. 180: 5177-5186.

CHUNG, Y., KO, S.Y., KO, H.J. and KANG, C.Y. (2005) Split peripheral tolerance: CD40 ligation blocks tolerance induction for CD8 T cells but not for CD4 T cells in response to intestinal antigens. Eur J Immunol. 35: 1381-1390.

DE MESTRE, A.M., KHACHIGIAN, L.M., SANTIAGO, F.S., STAVKOVA, M.A., and HULETT, M.D. (2003). Regulation of inducible heparanase gene transcription in activated T cells by early growth response 1. J. Biol. Chem. 278: 5037750385.

DE MESTRE, A. M., BACON, S. J., COSTA, C. C., LEADBEATER, J. C., NORONHA L. E., STEWART, F., and ANTCZAK, D. F. (2008) Modeling trophoblast differentiation using equine chorionic girdle vesicles. Placenta 29: 158-169.

DONALDSON, W.L., ZHANG, C.H., ORIOL, J.G., and ANTCZAK, D.F. (1990) Invasive equine trophoblast expresses conventional class I Major Histocompatibility Complex antigens. Development 110: 63-71.

DONALDSON, W.L., ORIOL, J.G., PLAVIN, A., and ANTCZAK, D.F. (1992) Developmental regulation of class I Major Histocompatibility Complex antigen expression by equine trophoblastic cells. Differentiation 52: 69-78.

DONALDSON, W.L., ORIOL, J.G., PELKAUS, C.L., and ANTCZAK, D.F. (1994) Paternal and maternal Major Histocompatibility Complex class I antigens are expressed co-dominantly by equine trophoblast. Placenta 15: 123-135.

ERLEBACHER, A., VENCATO, D., PRICE, K.A., ZHANG, D. and GLIMCHER, L.H. (2007) Constraints in antigen presentation severely restrict $T$ cell recognition of the allogeneic fetus. J Clin Invest. 117: 1399-1411.

FAAS, M.M., BOUMAN, A., VEENSTRA VAN NIEUWENHOVEN, A.L., VAN DER SCHAAF, G., MOES, H., HEINEMAN, M.J. and DE VOS, P. (2005) Species differences in the effect of pregnancy on lymphocyte cytokine production between human and rat. J Leukoc Biol. 78: 946-953.

FENG, G., WOOD, K. J. and BUSHELL, A. (2008) Interferon-gamma Conditioning Ex Vivo Generates CD25+CD62L+Foxp3+ Regulatory T Cells That Prevent Allograft Rejection: Potential Avenues for Cellular Therapy. Transplantation. 86: 578-589.

FLAMINIO, M. J. B. F. and ANTCZAK, D. F. (2005) Inhibition of lymphocyte proliferation and activation: a mechanism used by equine invasive trophoblast to escape the maternal immune response. Placenta 26: 148-159.

FLYNN, L., CARTON, J., BYRNE, B., KELEHAN, P., O'HERLIHY, C. and O'FARRELLY, C. (1999) Optimisation of a technique for isolating lymphocyte subsets from human endometrium. Immunol Invest. 28: 235-246.

GRÜNIG, G., TRIPLETT, L., CANADY, L.K., ALLEN, W.R., and ANTCZAK, D. F. (1995) The maternal leukocyte response to the endometrial cups in horses is correlated with the developmental stages of the invasive trophoblast cells. Placenta 16: 539-559.

HUNZIKER, R.D., LYNCH, F., SHEVACH, E.M., and MARGULIES, D.H. (1997) Split tolerance to the MHC class I molecule H-2Dd in animals transgenic for its soluble analog. Hum. Immunol. 52: 82-94.

HUNT, J. S. (2006) Stranger in a strange land. Immunol Rev. 2006 213: 36-47.

JIANG, S.P. and VACCHIO, M.S. (1998) Multiple mechanisms of peripheral T cell tolerance to the fetal "allograft." J. Immunol. 160: 3086-3090.

KANELLOPOULOS-LANGEVIN, C., CAUCHETEUX, S.M., VERBEKE, P. and OJCIUS, D.M. (2003) Tolerance of the fetus by the maternal immune system: role of inflammatory mediators at the feto-maternal interface. Reprod. Biol. Endocrinol. 1: 121.

$\mathrm{KOCH}, \mathrm{C} . \mathrm{A}$. and PLATT, J. L. (2003) Natural mechanisms for evading graft rejection: the fetus as an allograft. Springer Semin Immunopathol. 25: 95-117.

KRISHNAN, L., GUILBERT, L.J., RUSSELL, A.S., WEGMANN, T.G., MOSMANN, T.R. and BELOSEVIC, M. (1996a) Pregnancy impairs resistance of C57BL/6 mice to Leishmania major infection and causes decreased antigen-specific IFN$\mathrm{G}$ response and increased production of T helper 2 cytokines. J. Immunol. 156 644.

KRISHNAN, L., GUILBERT, L.J., WEGMANN, T.G., BELOSEVIC, M. and MOSMANN, T.R. (1996b) T helper 1 response against Leishmania major in pregnant $\mathrm{C} 57 \mathrm{BL} / 6$ mice increases implantation failure and fetal resorptions: correlation with increased IFN-G and TNF and reduced IL-10 production by placental cells. J. Immunol. 156: 653

LAZARY, S., ANTCZAK, D.F., BAILEY, E., BELL, T.K., BERNOCO, D., BYRNS, G. and MCCLURE, J. (1988) Joint Report of the Fifth International Workshop on Lymphocyte Alloantigens of the Horse. Anim. Genet. 19: 447-456.

LUNN, D.P., HOLMES, M.A., ANTCZAK, D.F., AGERWAL, N., BAKER, J., BENDALIAHCENE, S., BLANCHARD-CHANNELL, M., BYRNE, K.M., CANNIZZO, K., DAVIS, W., HAMILTON, M.J., HANNANT, D., KONDO, T., KYDD, J.H., MONIER, M.C., MOORE, P.F., O'NEIL, T., SCHRAM, B.R., SHEORAN, A., STOTT, J.L., SUGIURA, T., and VAGNONI, K.E. (1998) Report of the Second Equine Leucocyte Antigen Workshop, Squaw Valley, California, July 1995. Vet. Immunol. Immunopath. 62: 101-143.

LUO, B., CHAN, W. F., SHAPIRO, A. M. and ANDERSON CC. (2007) Nonmyeloablative mixed chimerism approaches and tolerance, a split decision. Eur $J$ Immunol. 37: 1233-1242.

MAHER, J.K., TRESNAN, D.P., DEACON, S., HANNAH, L., and ANTCZAK, D. F. (1996) Analysis of MHC class I gene expression in equine trophoblast cells using in situ hybridization. Placenta 17: 351-359.

MATHES, D. W., RANDOLPH, M. A., SOLARI, M. G., NAZZAL, J. A., NIELSEN, G. P., ARN, J. S., SACHS, D.H. and LEE, W. P. (2003) Split tolerance to a composite tissue allograft in a swine model. Transplantation 75: 25-31.

MEDAWAR, P. B. (1953) Some immunological and endocrinological problems raised by the evolution of viviparity in vertebrates. Symp. Soc. Exp. Biol. 11:320338.

MELLOR, A.L. and MUNN, D.H. (2000) Immunology at the maternal-fetal interface: lessons for T cell tolerance and suppression. Annu. Rev. Immunol. 18: 367-391.

MOFFETT, A. and LOKE, C. (2006) Immunology of placentation in eutherian mammals. Nat Rev Immunol. 2006 6: 584-594.

NAGLER-ANDERSON, C., BHAN, A.K., PODOLSKY, D.K., and TERHORST, C. (2004) Control freaks: immune regulatory cells. Nat. Immunol. 5: 119-122.

OLIVEIRA, L. and HANSEN, P. (2008) Deviations in populations of peripheral blood mononuclear cells and endometrial macrophages in the cow during pregnancy. Reproduction 136: 481-490.

PEJCIC-KARAPETROVIC, B., GURNANI, K., RUSSELL, M. S., FINLAY, B. B., SAD, S. and KRISHNAN, L. (2007) Pregnancy impairs the innate immune resistance to Salmonella typhimurium leading to rapid fatal infection. J/mmunol. 79: 6088-6096.

QIAN, S., LU, L., LI, Y., FU, F., LI, W., STARZL, T.E., THOMSON, A.W., and FUNG, J.J. (1997) Apoptosis of graft-infiltrating cytotoxic T cells: a mechanism underlying "split tolerance" in mouse liver transplantation. Transplant Proc. 29: 11681169.

RAMSDELL, F. (2003) Foxp3 and natural regulatory T cells: key to a cell lineage? Immunity 19: 165-168

ROBERSTON, S.A., MAU, V.J., HUDSON, S.N., and TREMELLEN, K.P. (1997) Cytokine leukocyte networks and the establishment of pregnancy. $A m$. J. Reprod. Immunol. 37: 438.

ROBERTSON, S.A. and SHARKEY, D.J. (2001) The role of semen in induction of maternal immune tolerance to pregnancy. Semin. Immunol. 13: 243-254.

SAITO, S., SASAKI, Y. and SAKAI, M. (2005) CD4(+)CD25high regulatory T cells in human pregnancy. $J$ Reprod Immunol. 65: 111-120. 
SASAKI, Y, DARMOCHWAL-KOLARZ, D., SUZUKI, D., SAKAI, M., ITO, M., SHIMA, T., SHIOZAKI, A., ROLINSKI, J. and SAITO, S. (2007) Proportion of peripheral blood and decidual $C D 4(+) \mathrm{CD} 25$ (bright) regulatory $\mathrm{T}$ cells in preeclampsia. Clin Exp Immunol. 149: 139-145.

SCAIFE, P.J., BULMER, J.N., ROBSON, S.C., INNES, B.A. and SEARLE, R.F. (2006) Effector activity of decidual CD8+ T lymphocytes in early human pregnancy. Biol Reprod. 75: 562-567.

SEAVEY, M. M. and MOSMANN, T. R. (2008) Immunoregulation of fetal and antipaternal immune responses. Immunol Res. 40: 97-113.

SOMERSET, D.A., ZHENG, Y., KILBY, M.D., SANSOM, D.M. \& DRAYSON, M.T. (2004) Normal human pregnancy is associated with an elevation in the immune suppressive CD25+ CD4+ regulatory T-cell subset. Immunology 112: 38-43.

SPRENT, J., HURD, M., SCHAEFER, M., and HEATH, W. (1995) Split tolerance in spleen chimeras. J. Immunol. 154: 1198-1206.

SMITH, J.L. (1999) Foodborne infections during pregnancy. J. Food. Prot. 62: 818829.

TAFURI, A., ALFERINK, J., MOLLER, P., HAMMERLING,G.J., and ARNOLD, B. (1995) T cell awareness of paternal alloantigens during pregnancy. Science 270: 630 .

TILBURGS, T., ROELEN, D.L., VAN DER MAST, B.J., VAN SCHIP, J.J., KLEIJBURG, C., DE GROOT-SWINGS, G.M., KANHAI, H.H., CLAAS, F.H. and SCHERJON, S.A. (2006) Differential distribution of CD4(+)CD25(bright) and CD8(+)CD28(-) T-cells in decidua and maternal blood during human pregnancy. Placenta 27 Suppl A: S47-53.

TILBURGS, T., ROELEN, D. L., VAN DER MAST, B. J., DE GROOT-SWINGS, G.
M., KLEIJBURG C., SCHERJON S. A. and CLAAS F. H. (2008) Evidence for a selective migration of fetus-specific CD4+CD25bright regulatory $T$ cells from the peripheral blood to the decidua in human pregnancy. J Immunol. 180: 5737 5745.

TROWSDALE, J. and BETZ, A. G. (2006) Mother's little helpers: mechanisms of maternal-fetal tolerance. Nat Immunol. 7: 241-246.

WAGNER, B., ROBESON, J., MCCRACKEN, M., WATTRANG, E., and ANTCZAK, D. F. (2005) Horse cytokine/lgG fusion proteins - mammalian expression of biologically active cytokines and a system to verify antibody specificity to equine cytokines. Vet. Immunol. Immunopathol. 105: 1-14.

WAGNER, B., HILLEGAS, J.M., ANTCZAK, D.F. (2006) A monoclonal antibody to equine interleukin-4. Vet Immunol Immunopathol. 110: 363-367.

WAGNER, B., HILLEGAS, J. M., BRINKER, D., HOROHOV, D. W., and ANTCZAK, D. F. (2008). Characterization of monoclonal antibodies to equine interleukin10 and detection of T regulatory 1 cells in horses. Vet. Immunol. Immunopathol. 122: $57-64$.

WOOD, K.J. and SAKAGUCHI, S. (2003) Regulatory T cells in transplantation tolerance. Nat. Rev. Immunol. 3: 199-210.

ZENCLUSSEN, A. C., GERLOF, K., ZENCLUSSEN, M. L., RITSCHEL, S., ZAMBON BERTOJA, A., FEST, S., HONTSU, S., UEHA, S., MATSUSHIMA, K., LEBER, J. and VOLK, H. D. (2006) Regulatory T cells induce a privileged tolerant microenvironment at the fetal-maternal interface. Eur J Immunol. 36: 82-94.

ZENCLUSSEN, A. C., SCHUMACHER, A., ZENCLUSSEN, M. L., WAFULA, P., and VOLK, H. D. (2007) Immunology of pregnancy: cellular mechanisms allowing fetal survival within the maternal uterus. Expert Rev Mol Med. 9: 1-14. 


\section{Further Related Reading, published previously in the Int. J. Dev. Biol.}

See our recent Special Issue Epigenetics \& Development edited by Saadi Khochbin and Stefan Nonchev at: http://www.ijdb.ehu.es/web/contents.php?vol=53\&issue=2-3

See Special Issue Pattern Formation edited by Michael K. Richardson and Cheng-Ming Chuong at: http://www.ijdb.ehu.es/web/contents.php?vol=53\&issue=5-6

Immunoregulatory molecules in human placentas: potential for diverse roles in pregnancy Joan S. Hunt, Judith L. Pace and Ryan M. Gill

Int. J. Dev. Biol. (2010) 54: 457-467 (doi: 10.1387/ijdb.082831jh)

Estrogen regulation of placental angiogenesis and fetal ovarian development during primate pregnancy Eugene D. Albrecht and Gerald J. Pepe

Int. J. Dev. Biol. (2010) 54: 397-408 (doi: 10.1387/ijdb.082758ea)

Critical growth factors and signalling pathways controlling human trophoblast invasion Martin Knöfler

Int. J. Dev. Biol. (2010) 54: 269-280 (doi: 10.1387/ijdb.082769mk)

Trisomy 21- affected placentas highlight prerequisite factors for human trophoblast fusion and differentiation

André Malassiné, Jean-Louis Frendo and Danièle Evain-Brion Int. J. Dev. Biol. (2010) 54: 475-482 (doi: 10.1387/ijdb.082766am)

Trophoblast phagocytic program: roles in different placental systems

Estela Bevilacqua, Mara-Sandra Hoshida, Andrea Amarante-Paffaro, Andrea Albieri-Borges and Sara Zago-Gomes

Int. J. Dev. Biol. (2010) 54: 495-505 (doi: 10.1387/ijdb.082761eb)

Spatiotemporal expression of the selenoprotein $\mathbf{P}$ genein postimplantational mouse embryos

Se-Ra Lee, Jung-Min Yon, In-Jeoung Baek, Mi-Ra Kim, Chun-Gui Park, Beom-Jun Lee, Young-Won Yun and Sang-Yoon Nam

Int. J. Dev. Biol. (2008) 52: 1005-1011

An activating mutation in the PDGF receptor-beta causes abnormal morphology in the mouse placenta

Camilla Looman, Tong Sun, Yang Yu, Agata Zieba, Aive Ahgren, Ricardo Feinstein, Henrik Forsberg, Carina Hellberg, Carl-Henrik Heldin, Xiao-Qun Zhang, Karin Forsberg-Nilsson, Nelson Khoo, Reinald Fundele and Rainer Heuchel

Int. J. Dev. Biol. (2007) 51: 361-370

A simple in vivo approach to investigate invasive trophoblast cells Juan A. Arroyo, Toshihiro Konno, Darya C. Khalili and Michael J. Soares Int. J. Dev. Biol. (2005) 49: 977-980

The Le Douarin phenomenon: a shift in the paradigm of developmental self-tolerance António Coutinho

Int. J. Dev. Biol. (2005) 49: 131-136

Commitment of hematopoietic stem cells in avian and mammalian embryos: an ongoing story

Françoise Dieterlen-Lièvre

Int. J. Dev. Biol. (2005) 49: 125-130

The introduction of Xenopus laevis into developmental biology: of empire, pregnancy testing and ribosomal genes.

J B Gurdon and N Hopwood

Int. J. Dev. Biol. (2000) 44: 43-50

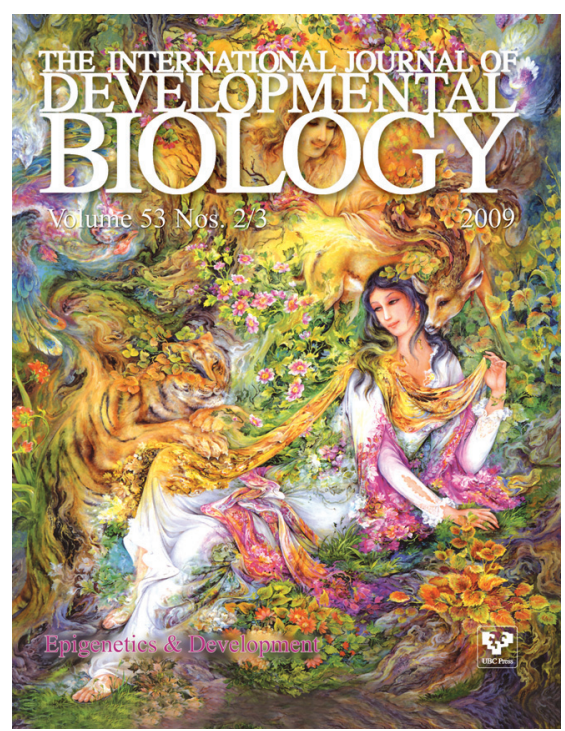

5 yr ISI Impact Factor $(2008)=3.271$

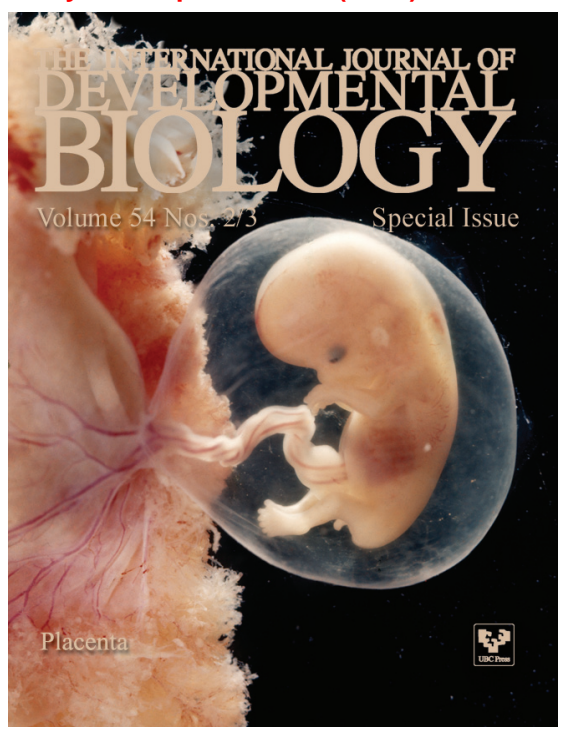

